\title{
Farmers' Behavioral Gaps Concerning Sustainable Agriculture in Kharga Oasis, New Valley Governorate, Egypt
}

\author{
Mohamed M. Yacoub ${ }^{1}$, Ahmed M. Diab ${ }^{2}$
}

\begin{abstract}
The aims of this research are to 1) assess farmers' behavior (knowledge, attitudes, and practices) concerning the sustainable agriculture (crop, land and water management) in Kharga Oasis, 2) explore farmers' behavioral gaps concerning the sustainable agriculture practices, and 3) determine variables related to farmers' behavior (knowledge, attitudes, and practices) concerning the sustainable agriculture in Kharga Oasis. In order to achieve the study's objectives, EI Mounira village had been randomly selected to be the place of this study. Data were collected from a sample of 120 respondents during February to March 2021 through personal interviews using a pre-tested questionnaire form. A list of thirty-three sustainable crop, soils and water management practices was developed based on reviewing the literature, Findings revealed that the overall mean value of respondents' knowledge on sustainable agriculture practices is $\mathbf{2 2 . 7 4}$ score which represents $68.91 \%$ of the total score, $84.1 \%$ for attitudes, and $55.3 \%$ for implementation of the studied practices. Considering the overall behavioral gaps, findings revealed that K-R gap -knowledge-recommended gap- is $16 \%$, which mean that farmers did not knew about $16 \%$ of the recommended knowledge, and the implementation-knowledge gap, I-K gap, is $5.3 \%$ this mean that farmers did not implement about $5.3 \%$ of practices they knew, and the I-R gap reached $21.39 \%$, this imply that farmers did not implement more the one fifth of the recommended sustainable agriculture practices. The gap of attitude-full positive attitude, A-F gap reached about $15.9 \%$, this mean that farmers need change $16 \%$ of their attitudes to reach the full positive attitudes towards the sustainable agriculture practices. Findings also showed that six variables are affects farmers' knowledge, attitudes towards and implementation of sustainable agriculture practices. These variables are age, farm size, farming experience, availability of agricultural drainage, adequacy of irrigation water in the summer season, and attitudes towards environment. Based on the obtained findings, some recommendations were formulated.
\end{abstract}

Key words: Farmers knowledge, attitudes, implementation, behavior, sustainable agriculture, New Valley, Egypt.

DOI: 10.21608/asejaiqjsae.2021.171647

${ }^{1}$ High Institute for Agricultural Cooperation (HIAC),

Ministry of Higher Education, Cairo, Egypt.

E-mail: mohamed.yacoub@fao.org

${ }^{2}$ Department of Rural Sociology and Agricultural Extension,

Faculty of Agriculture, New Valley University, Kharga, Egypt.

Email: a.diab@nvu.edu.eg (correspondence author)

Received April 20, 2021, Accepted, May 23, 2021.

\section{INTRODUCTION}

Many literature indicate that it is necessary to organize the economy according to sustainable development principles, agriculture is one of the economy's branches that has a significant impact on shaping the non-renewable natural environment, this impact is related to the direct use of environmental resources in production processes (Gebska, et al., 2020).

Recently, agriculture has changed dramatically, the productivity raised due to new technologies, mechanization, increased chemical use, specialization and government policies that favored maximizing production (Abubakar \& Attanda, 2013). The intensification of agricultural production requires the use of many industrial inputs (i.e., mineral fertilizers and chemical pesticides), and their excessive use can cause a significant threat to the environment (Amani, et al., 2007).

There are many factors causing environmental degradation in agricultural activities including improper farm management within the farm and improper waste management. The degree of the negative impact of agricultural production on the environment depends on the farm type and production system (Le Gal, et al., 2011; Gebska, et al., 2020). Agricultural production is heterogeneous in terms of farm type, this factor is vital for its environmental impact, moreover, agricultural operations worldwide generate growing concerns about their environmental impact (Le Gal, et al., 2011).

Sustainable agriculture is a philosophy or system that, over the long term, enhances environmental quality and the resource base on which agriculture depends; provides for changing human needs; is economically viable; and enhances the quality of life for farmers and society as a whole (Crews, et al., 1991; Flora, 1992; Karami, 1995; Chikwendu \& Arokoyo, 1997; Kambewa, 2007 Curry, et al., 2012). The Food and Agriculture Organization defined sustainable agriculture as "production which fulfils food security, 
environmental protection, and economic and social needs in rural areas (FAO, 2014). The adjectives biological, organic, ecological, alternative, regenerative, natural and low input are commonly used to refer to seemingly similar concepts of sustainable agriculture (Weil, 1990).

Three broad areas of concern seem to underlie the concept of sustainable agriculture (Weil, 1990): i) economic concerns over economic justice, the survival of owner operated farms, and the long-term profitability of agriculture; ii) environmental concerns over adverse impacts of agriculture on soils, water, and wildlife resources; and iii) public welfare concerns over food quality and human health.

Government, academic, and business entities that ignored nonconventional systems in the past are now actively promoting the concept of sustainability in their programs (Weil, 1990). Implementing sustainable practices at farms may reduce the undesirable effects resulting from agricultural activities. In fact, different production methods can be used in plant production to ensure its sustainability. They include, among others, precision production, conservation, organic agriculture, and integrated agro-farming systems (Gebska, et al., 2020). Sustainable agriculture practices should be consistent with certain principles of sustainability, including the preservation of the productive capacity of soil, saving water resources, avoidance of off-farm pollution and environmental degradation (Crosson, 1992; Abubakar \& Attanda, 2013). This task is complex, because it involves human activities such as a farm management and agricultural policies and many other factors such as climate conditions, terrain, soil type, gas emissions from animals (Kielbasa, et al., 2016).

Farmers, as the first, and as many would argue, most crucial link of the agri-food value chain are key in achieving sustainability of the entire value chain. Farming is an activity that involves daily decisiontaking related to external factors, such as the economic and physical environment in which the farmer operates or to internal factors such as agricultural production and the financial operation of the farm (Herberich \& List, 2012). The strategies farmers employ to behave with sustainable agriculture depend on their knowledge and attitudes (Nastis, et al., 2019).

Many researchers adapt Bloom's taxonomy of instructional objectives into a multi-construct approach to assessment that evaluates not only knowledge, but attitude and behavioral change as well (Schrader and Lawless, 2004). With respect to Bloom's taxonomy, the cognitive domain of the learned behavior is concerned with knowledge and understanding. Within a domain, knowledge embodies all information that a person possesses or accrues related to a particular field of study (Alexander \& Jetton, 2000; Alexander, Jetton, \& Kulikowich, 1995). Knowledge is generally defined as comprising three forms: (1) declarative, or knowing what, (2) procedural, or knowing $\mathrm{h} o \mathrm{w}$, and (3) conditional, or knowing when and why. The successful transition to sustainable agriculture depends on local farmers' knowledge, which is a crucial factor in the forming farmers' behaviors (Sumane, et al., 2018; Eckert \& Bell, 2005).

Similar to knowledge, the concept of attitude has multiple meanings to researchers, all definitions agree that an attitude is a state of the mind, a set of views, or thoughts, regarding some topic (called the 'attitude object'), which have an evaluative feature (positive, negative or neutral quality). It is accompanied by an emotional component, and a tendency to act in a particular way with regard to the attitude object. Perhaps the most fundamental assumption underlying the attitude concept is the notion that attitudes in some way, guide, influence, direct, shape, or predict actual behavior (Kraus, 1995; Holdershaw \& Gendall, 2008). Farmers' positive attitudes towards sustainable agriculture emerged as the best predictors of implementation of such practices (Alonge \& Martin, 1995).

Farmers' implementation generally reflects farmers' expertise and ethics. The implementation of sustainable agriculture requires improvements in farmers' knowledge and enhance the positive attitudes towards its technologies (Pretty, et al., 2011).

Interaction of knowledge, attitudes, and practice could be justified by what an individual knows may form his or her attitude about that topic, and how he or she feels about that topic may influence behavior (Schrader and Lawless, 2004). Farmers' perception of the sustainable agriculture, and their attitudes towards and implementation of various practices to improve the degree of sustainable agriculture have been analyzed in this paper. Specifically, the aims are to:

1. Assess farmers' behavior (knowledge, attitudes, and implementation) concerning the sustainable agriculture (crop, land and water management) in Kharga Oasis.

2. Explore farmers' behavioral gaps concerning the sustainable agriculture practices.

3. Determine variables related to farmers' behavior (knowledge, attitudes, and implementation) concerning the sustainable agriculture in Kharga Oasis.

\section{Methodology}

The New Valley governorate (with five administrative districts) is located in the south west part 
of western desert of Egypt. It represents about $44 \%$ from the total area of Egypt, and $67 \%$ of the total area of Egyptian western desert (Figure 1). The New Valley representative a key future of development in Egypt in terms of land reclamation and new place for settlements to overcome the excessive population growth in Egypt. For example, the presence of virgin soils considered to be important factors which play a vital role for development. Furthermore, its natural geographic formation of good sight-seeing and therapeutic tourism emphasizes the importance of New Valley for development in Egypt.

In order to achieve the study's objectives, Kharga oasis was selected from the New Valley's five districts. After that, one village (El Mounira) had been randomly selected to be the place of this study. A sample of (120 Farmers) representing a percentage of $10 \%$ of total farmers in this village (1202 farmers) were selected for the empirical study. Data were collected from the respondents during February to March 2021 through personal interviews using a pre-tested questionnaire form.

The questionnaire form include a list of sustainable plant, soils and water management practices was collected form literature (Alonge \& Martin, 1995; Abdel-Salam, 2011; Diab \& Diab, 2016; Diab \& Tohamy, 2016; Kielbasa, et al., 2018; Sumane, et al., 2018) then reviewed and validated by five experts on plant, soils and water. The list consists of thirty three sustainable agriculture practices divided into three subscales: 1) sustainable plant management practices (14 items), 2) sustainable soils management practices (12 items), and 3) sustainable water management practices (7 items) as shown in table 1.

In order to measure farmers' behaviors on sustainable agriculture, respondents were asked to determine their knowledge and implementation of those practices, their responses were scored as 0 for do not know or do not implement and 1 for knew or implement, respectively, then the respondents' knowledge and implementation levels were categorized into three categories for plant management practices (low: 0-4; medium: 5-9; high: 10-14), for soils management practices (low: 0-3; medium: 4-8; high: 912), and for water management practices (low: 0-2; medium: 3-4; high: 5-7). The overall sustainable agriculture scale was categorized into three categories as (low: 0-10; medium: 11-22; high: 23-33).

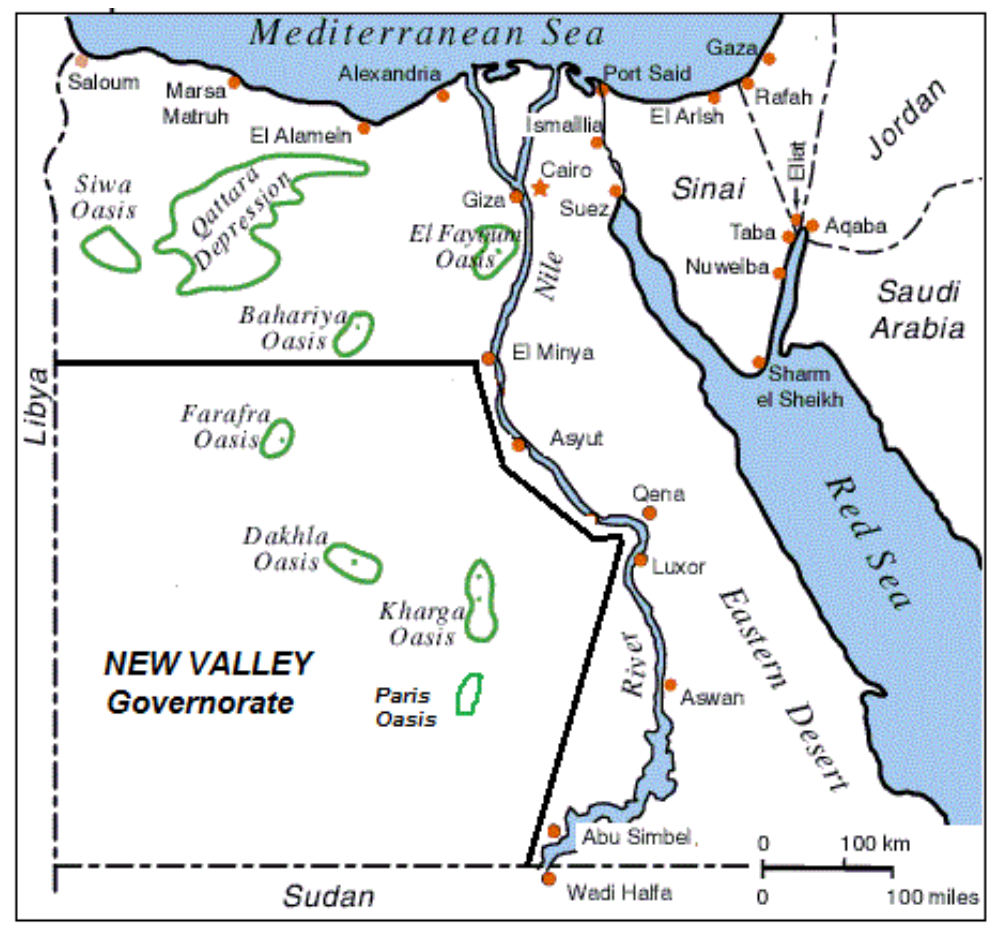

Fig. 1. Map of study location (New Valley, Egypt) 
Table 1. List of sustainable agriculture practices

\begin{tabular}{|c|c|}
\hline No. & Sustainable Agriculture Practices \\
\hline & Sustainable plant management practices \\
\hline 1. & Follow the crop rotation \\
\hline 2. & Using windbreaks to protect crops from diseases and pests \\
\hline 3. & Follow recommended dates and quantities for using chemical fertilizers \\
\hline 4. & Utilization of wild plants and herbs for recommended medication or animal feeding \\
\hline 5. & Cultivate fodder crops for animal feedings \\
\hline 6. & Cultivate some plants around the main crop as botanical traps to attract the insects and protect the main crop \\
\hline 7. & Manual collection of insects, infestations and weeds \\
\hline 8. & Cultivation of disease resistant varieties \\
\hline 9. & Using alternatives of pesticides (phosphorus / sulfur / yeast and molasses, etc.) \\
\hline 10. & Intercropping or using legumes in the agricultural rotation \\
\hline 11. & Using biocontrol methods to control weeds, diseases and insects \\
\hline 12. & Cultivating on terraces or on lines instead of ponds \\
\hline 13. & Utilizing crop residues to produce fertilizer or fodder or mulching \\
\hline \multirow[t]{2}{*}{14.} & Cultivation of the stress tolerant varieties (heat/drought/salinity) \\
\hline & Sustainable soils management practices \\
\hline 1. & Using mechanization (plowing, lining and soil conservation) \\
\hline 2. & Organic fertilization (utilization of farm and animal wastes) \\
\hline 3. & Using laser in soil surface levelling \\
\hline 4. & Bio-fertilization \\
\hline 5. & Utilization of windbreaks to sand stabilization \\
\hline 6. & Regular maintenance of the agricultural drains \\
\hline 7. & Follow crop rotation to preserve soil fertility \\
\hline 8. & Using of agricultural machinery to chop crop residues and reuse it as a fertilizer for the soil \\
\hline 9. & Preserving soils from non-agricultural uses (mooring soil, construction etc.) \\
\hline 10. & Cultivation on lines perpendicular to the wind to sand stabilization \\
\hline 11. & Avoid moving organic fertilizers and soil from weeds and fungi infected areas \\
\hline \multirow[t]{2}{*}{12.} & Using mulch to cover the soil surface \\
\hline & Sustainable water management practices \\
\hline 1. & Follow the modern irrigation systems (sprinkler / drip / gated pipe etc..) \\
\hline 2. & Irrigate crops at early morning or evening instead of afternoon \\
\hline 3. & Cultivating salt-tolerant varieties \\
\hline 4. & Regularly cleansing and maintaining of irrigation canals \\
\hline 5. & Avoiding over-exploitation of ground water \\
\hline 6. & Follow the recommendations for the dates and number of watering for each crop \\
\hline 7. & Using of laser in soil surface leveling to conserve irrigation water \\
\hline
\end{tabular}

Source: review of literature

Also, respondents were asked to determine their attitudes towards those practices on a scale of agree to disagree (their responses were scored as 2 for agree, 1 for neutral and 0 for disagree). Based on the scoring method, respondents were categorized into three categories for attitudes towards sustainable plant management (negative: 0-8; neutral: 9-18; positive: 1928), attitudes towards sustainable soils management (negative: 0-7; neutral: 8-15; positive: 16-24), attitudes towards sustainable water management (negative: 0-4; neutral: 5-9; positive: 10-14), and the overall attitudes towards sustainable agriculture (negative: 0-21; neutral: 22-44; positive: 45-66). The relative weight (RW) or weighted average was calculated according the following formula after giving weights of 1,2 , and 3 for the categories of low, medium and high, respectively.

Relative weight (RW)

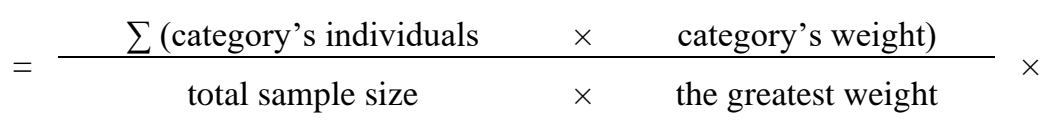


The questionnaire also included sets of questions to measure about 15 variables related to farmers' socioeconomic status, as follows: 1) age: measured by years old at data collection time, 2) education: 0 for Illiterate; 1 for read and write; 2 for having primary or preparatory school; 3 for secondary school degree, and 4 for university degree, 3) Family size: measured by row family size as indicated by respondent, 4) Occupation: respondents were asked to determine their occupation as farmer only, farmer and governmental employee or farmer and private or self-employee, 5) Farmland ownership was measured by number of feddans owned by the respondent, then categorized into five categories as Less than 2 feddans; 2 and less than 5; 5 and less than 10; 10 and less than 20; and 20 and more feddans, 6) Farming experience: measured by number of years the respondents practice the agriculture as a profession, 7) The adequacy of the income measured by respondents' decision on that they gain not enough, to some extent or enough income, 8) Attitudes towards environment conservation: respondents were asked to determine their opinion of 15 environmental-related statements on a three Likert scale ( 0 for disagree, 1 for neutral, 2 for agree), then the overall responses were divided into three categories as: negative: 0-9, neutral: 10-19, positive: 20-30. The remaining variables are measured according respondents' selection from the corresponding choices.

In order to achieve the third objective, forty-five statistical hypotheses were formulated as follows: farmers' knowledge on sustainable agriculture is not affected by the fifteen studied variables (hypotheses form 1-15); farmers' attitudes towards the sustainable agriculture is not affected by the fifteen studied variables (hypotheses form 16-30); and farmers' implementation of sustainable agriculture practices is not affected by the fifteen studied variables (hypotheses form 31-45). Frequencies, percentages, range, average, standard deviation, weighted average (relative weight), and Chi-square were used for data processing and presentation.

Data in table 2 indicates the distribution of farmers according to their personal and socioeconomic characteristics; it became clear that the majority of respondents $(73.3 \%)$ were aged 40 years or more, have secondary or more educational level $(81.7 \%)$, have less than 5 person-families (53.3\%), own less than five feddans $(38.3 \%)$, are governmental employed beside practice agriculture $(47.5 \%)$, have 15 or years of farming experience, and have positive attitudes towards the environment conservation (79.2\%). Concerning to economic characteristics, findings show that there are significant percentage of farmers own (or have a share) a non-deep well $(37.5 \%)$, using traditional irrigation methods $(83.3 \%)$, have shortages in irrigation water specially in the summer season (95\%), own farm animal (93.3\%), do not own agricultural machineries (78.3\%), suffering from poverty or inadequately of income $(81.6 \%)$.

\section{RESULTS \& DISCUSSIONS}

\section{Farmers' behavior concerning the sustainable agriculture}

Findings in tables 3, 4, and 5 show knowledge, attitudes and implementation of sustainable agriculture. It could be realized that the overall mean value of respondents' knowledge on sustainable agriculture practices is 22.74 score which represents $68.91 \%$ of the total score; this implies that farmers have a good but not excellent knowledge on sustainable agriculture practices, more efforts should be done to fill the knowledge gap of $31.1 \%$.

Findings in table 3 also revealed that subscales of sustainable management practices could be ranked according the relative weight as Sustainable water management $(95.83 \%)$, followed by Sustainable soils management $(80.83 \%)$ and finally the component of "Sustainable crop management" (77.22\%).

Table 4 show mean scores and frequency and percentages distribution of farmers attitudes towards the sustainable agriculture practices. Findings realized that the respondents' overall attitudes towards sustainable agriculture practices is 55.5 which represents $84.1 \%$ of the total score; this implies that respondents are entirely have positive attitudes towards sustainable agriculture practices. The table also revealed that subscales could be ranked as "Sustainable soils management" (98.89\%) followed by "Sustainable water management" (98.33\%) and "Sustainable plant management" (95.56\%). This may facilitate the effort needed to diffusion and adoption of sustainable agriculture practices among farmers in the study area.

Table 5 show mean scores and frequency and percentages distribution of farmers implementation of the sustainable agriculture practices. It could be realized that the overall mean value of respondents' implementation of sustainable agriculture practices is 18.25 score which represents $55.3 \%$ of the total score; this implies that farmers implement only near fifty percent of the recommended sustainable agriculture practices. By comparing this result with their knowledge level, it is become clear that they implement only $80.25 \%$ of practices that they already knew.

Findings in table 5 also revealed that farmers' implementation of sustainable management practices subscales could be ranked according the relative weight 
as Sustainable water management $(84.72 \%)$, followed by Sustainable soils management $(69.17 \%)$ and finally the component of "Sustainable crops management" $(65.28 \%)$.

Table 2. Characteristics of respondents $(n=120)$

\begin{tabular}{|c|c|c|c|c|c|}
\hline Variables & Number & $\%$ & Variables & Number & $\%$ \\
\hline Age & & & Education & & \\
\hline Less than 30 years & 4 & 3.3 & Illiterate & 10 & 8.3 \\
\hline $30-$ & 28 & 23.3 & Read and write & 7 & 5.8 \\
\hline 40 - & 33 & 27.5 & Primary/ Preparatory & 5 & 4.2 \\
\hline $50-$ & 31 & 25.8 & Secondary & 63 & 52.5 \\
\hline $60-$ & 24 & 20.0 & University & 35 & 29.2 \\
\hline Family Size & & & Occupation & & \\
\hline Less than 5 persons & 64 & 53.3 & Farmer only & 54 & 45.0 \\
\hline $5-$ & 52 & 43.3 & Farmer and governmental employee & 57 & 47.5 \\
\hline $10-$ & 4 & 3.3 & $\begin{array}{l}\text { Farmer and private sector or self- } \\
\text { employee }\end{array}$ & 9 & 7.5 \\
\hline Farm Size & & & Farming experience & & \\
\hline Less than 2 feddans & 7 & 5.8 & Less than 15 years & 25 & 20.8 \\
\hline $2-$ & 39 & 32.5 & $15-$ & 46 & 38.3 \\
\hline $5-$ & 54 & 45.0 & $30-$ & 49 & 40.8 \\
\hline $10-$ & 11 & 9.2 & $\begin{array}{l}\text { Availability of agricultural } \\
\text { drainage }\end{array}$ & & \\
\hline \multirow[t]{2}{*}{$20-$} & 6 & 5.0 & No & 90 & 75.0 \\
\hline & & & Yes & 30 & 25.0 \\
\hline Source of irrigation water & & & Type of irrigation system & & \\
\hline Non-deep well & 45 & 37.5 & Traditional & 100 & 83.3 \\
\hline Deep well & 44 & 36.7 & Improved & 7 & 5.8 \\
\hline Both (Deep and nondeep well) & 31 & 25.8 & Both (traditional and improved) & 13 & 10.8 \\
\hline \multicolumn{3}{|c|}{ Adequacy of irrigation water in the winter season } & \multicolumn{3}{|c|}{ Adequacy of irrigation water in the summer season } \\
\hline Not enough & 3 & 2.5 & Not enough & 47 & 39.2 \\
\hline To some extent & 12 & 10.0 & To some extent & 67 & 55.8 \\
\hline Enough & 105 & 87.5 & Enough & 6 & 5.0 \\
\hline Farm animal ownership & & & Agricultural machinery ownership & & \\
\hline No & 8 & 6.7 & No & 94 & 78.3 \\
\hline Yes & 112 & 93.3 & Yes & 26 & 21.7 \\
\hline The adequacy of the income & & & Attitudes towards environment & & \\
\hline Not enough & 25 & 20.8 & Negative $(0-9)$ & 0 & 0 \\
\hline To some extent & 73 & 60.8 & Neutral (10-19) & 25 & 20.8 \\
\hline Enough & 22 & 18.3 & Positive $(20-30)$ & 95 & 79.2 \\
\hline
\end{tabular}

Source: the study's findings

Table 3. Farmers' knowledge on sustainable agriculture practices

\begin{tabular}{|c|c|c|c|c|c|c|c|c|c|c|c|}
\hline \multirow[t]{2}{*}{ sustainable agriculture } & \multirow[t]{2}{*}{ Max. } & \multirow[t]{2}{*}{ Mean } & \multirow[t]{2}{*}{ S.D. } & \multicolumn{2}{|c|}{$\begin{array}{c}\text { Low } \\
\text { Category }\end{array}$} & \multicolumn{2}{|c|}{$\begin{array}{l}\text { Medium } \\
\text { Category }\end{array}$} & \multicolumn{2}{|c|}{$\begin{array}{c}\text { High } \\
\text { Category }\end{array}$} & \multirow[t]{2}{*}{ R.W. } & \multirow[t]{2}{*}{ Rank } \\
\hline & & & & $\mathbf{F}$ & $\%$ & $\mathbf{F}$ & $\%$ & $\mathbf{F}$ & $\%$ & & \\
\hline Sustainable crop management practices & 14 & 8.70 & 2.60 & 5 & 4.2 & 72 & 60.0 & 43 & 35.8 & 77.22 & 3 \\
\hline Sustainable soil management practices & 12 & 8.13 & 1.94 & 1 & 0.8 & 67 & 55.8 & 52 & 43.3 & 80.83 & 2 \\
\hline Sustainable water management practices & 7 & 5.91 & 1.24 & 3 & 2.5 & 9 & 7.5 & 108 & 60 & 95.83 & 1 \\
\hline Overall sustainable agriculture & 33 & 22.74 & 4.18 & 1 & 0.8 & 56 & 46.7 & 63 & 52.5 & - & - \\
\hline
\end{tabular}

Source: The study's findings 
Table 4. Farmers' attitudes towards sustainable agriculture practices

\begin{tabular}{lccccccccccc}
\hline \multirow{2}{*}{ Sustainable Agriculture } & \multirow{2}{*}{ Max. } & \multirow{2}{*}{ Mean } & \multirow{2}{*}{ S.D. } & \multicolumn{2}{c}{ Negative } & \multicolumn{2}{c}{ Neutral } & \multicolumn{2}{c}{ Positive } & \multirow{2}{*}{ R.W. } & \multirow{2}{*}{ Rank } \\
\hline Sustainable crop management practices & 28 & 23.00 & 3.52 & 0 & 0 & 16 & 13.3 & 104 & 86.7 & 95.56 & 3 \\
Sustainable soil management practices & 24 & 20.19 & 2.78 & 0 & 0 & 4 & 3.3 & 116 & 96.7 & 98.89 & 1 \\
Sustainable water management practices & 14 & 12.31 & 1.67 & 0 & 0 & 6 & 5.0 & 114 & 95.0 & 98.33 & 2 \\
Overall sustainable agriculture & 66 & 55.50 & 6.71 & 0 & 0 & 6 & 5.0 & 114 & 95.0 & - & - \\
\hline
\end{tabular}

Source: The study's findings

Table 5. Farmers' implementation of sustainable agriculture practices

\begin{tabular}{|c|c|c|c|c|c|c|c|c|c|c|c|}
\hline \multirow[t]{2}{*}{ Sustainable Agriculture } & \multirow[t]{2}{*}{ Max. } & \multirow[t]{2}{*}{ Mean } & \multirow[t]{2}{*}{ S.D. } & \multicolumn{2}{|c|}{$\begin{array}{c}\text { Low } \\
\text { Category }\end{array}$} & \multicolumn{2}{|c|}{$\begin{array}{l}\text { Medium } \\
\text { Category }\end{array}$} & \multicolumn{2}{|c|}{$\begin{array}{c}\text { High } \\
\text { Category }\end{array}$} & \multirow[t]{2}{*}{ R.W. } & \multirow{2}{*}{$\begin{array}{l}\text { Ra } \\
\text { nk }\end{array}$} \\
\hline & & & & $\mathbf{F}$ & $\%$ & $\mathbf{F}$ & $\%$ & $\mathbf{F}$ & $\%$ & & \\
\hline Sustainable crop management practices & 14 & 6.94 & 2.66 & 23 & 19.2 & 79 & 65.8 & 18 & 15.0 & 65.28 & 3 \\
\hline Sustainable soil management practices & 12 & 6.41 & 2.44 & 11 & 9.2 & 89 & 74.2 & 20 & 16.6 & 69.17 & 2 \\
\hline Sustainable water management practices & 7 & 4.90 & 1.55 & 10 & 8.3 & 35 & 29.2 & 75 & 62.5 & 84.72 & 1 \\
\hline Overall sustainable agriculture & 33 & 18.25 & 5.33 & 8 & 6.7 & 90 & 75 & 22 & 18.3 & - & - \\
\hline
\end{tabular}

Source: The study's findings

\section{Farmers' behavioral gaps of sustainable agriculture}

Findings in table 6 and figure 2 show farmers' behavioral gaps concerning sustainable agriculture, there are three types of gaps as follow: 1) type-1 gap is the knowledge-recommended gap, K-R gap, calculated by subtracting the knowledge mean scores (of each subscale) from the maximum score for sustainable recommended practices, 2) type- 2 gap is an implementation-knowledge gap, I-K gap, calculated by subtracting the implementation mean scores (of each subscale) from the corresponding knowledge score, 3) type-3 gap is an implementation-recommended gap, I-R gap, calculated by subtracting the implementation scores (of each subscale) from the recommended practices score, and 4) type-4 gap, A-F gap, is the attitude-full positive attitude gap, it calculated by subtracting the score of attitudes (for each subscale) from the full positive attitude score

Findings in table 6 show that the widest knowledge gap (Type-1 gap or K-R gap) is to "Sustainable crop management practices" with value of $37.9 \%$, followed by the knowledge gap of "Sustainable soil management practices" $(32.25 \%)$, this result implies that more awareness efforts should be spent to provide farmers with knowledge on sustainable crop and soil management practices. The narrower knowledge gap was to "Sustainable water management practices" with value of $15.6 \%$, farmer knew about $85 \%$ of knowledge that should be known.

Data in the same table show that farmers did not implement $15 \%$ of knowledge they knew on soil and water management practices, this is illustrated by the value of type- 2 gap, I-K gap, which reaches about $15 \%$ for each. This gap goes more narrower for crop management practices to reach $12.6 \%$. these findings much efforts should be spent to enhance the implementation of known practices on crop and soils management. With regard the type-3 gaps (I-R gap), findings revealed that farmers did not implement more than half of the recommended sustainable practices for crop management (the I-R gap is $50.43 \%$ ), they also did not implement only $46.6 \%$ of recommended sustainable soil management practices (I-R gap of $46.6 \%$ ) and did not implement about $30 \%$ of the recommended practices on sustainable water management practices (I-R gap is $30 \%)$.

For the type-4 gap, A-F gap, findings revealed that crop management practices gain the widest attitude-full positive attitude gap with score of $17.86 \%$, followed by soil management practices (15.9\%), and finally the A-F gap of water management practices (A-F is $12.1 \%$ ).

Considering the overall behavioral gaps, findings in table 6 revealed that K-R gap -knowledge gap- is $16 \%$, which mean that farmer did not knew about $16 \%$ of the recommended knowledge, and the implementation gap, $\mathrm{I}-\mathrm{K}$ gap, is $5.3 \%$ this mean that farmers did not implement about $5.3 \%$ of practices they knew. Findings also show that I-R gap reached $21.39 \%$, this imply that farmers did not implement more the one fifth of the recommended sustainable agriculture practices. The attitude-full positive attitude gap, A-F gap reached about $15.9 \%$, this mean that farmers need change $16 \%$ of their attitudes to reach the full positive attitudes towards the sustainable agriculture practices. 
Table 6. farmers' behavioral gaps of sustainable agriculture

\begin{tabular}{lcccccccc}
\hline & \multicolumn{2}{c}{$\begin{array}{c}\text { K-R Gap } \\
\text { Knowledge - } \\
\text { Sustainable agriculture }\end{array}$} & \multicolumn{2}{c}{$\begin{array}{c}\text { I-K Gap } \\
\text { Implementation - } \\
\text { Knommended }\end{array}$} & \multicolumn{2}{c}{$\begin{array}{c}\text { I-R Gap } \\
\text { Implementation - } \\
\text { Recommended }\end{array}$} & $\begin{array}{c}\text { A-F Gap } \\
\text { Attitudes - Full } \\
\text { Positive Attitude }\end{array}$ \\
\cline { 2 - 10 } & Value & $\mathbf{\%}$ & Value & \% & Value & \% & Value & \% \\
\hline Sustainable crop management practices & -5.3 & -37.86 & -1.76 & -12.57 & -7.06 & -50.43 & -5 & -17.86 \\
Sustainable soil management practices & -3.87 & -32.25 & -1.72 & -14.33 & -5.59 & -46.58 & -3.81 & -15.88 \\
Sustainable water management practices & -1.09 & -15.57 & -1.01 & -14.43 & -2.1 & -30.00 & -1.69 & -12.07 \\
Overall sustainable agriculture & -5.3 & -16.06 & -1.76 & -5.33 & -7.06 & -21.39 & -10.5 & -15.91 \\
\hline
\end{tabular}

Source: The study's findings

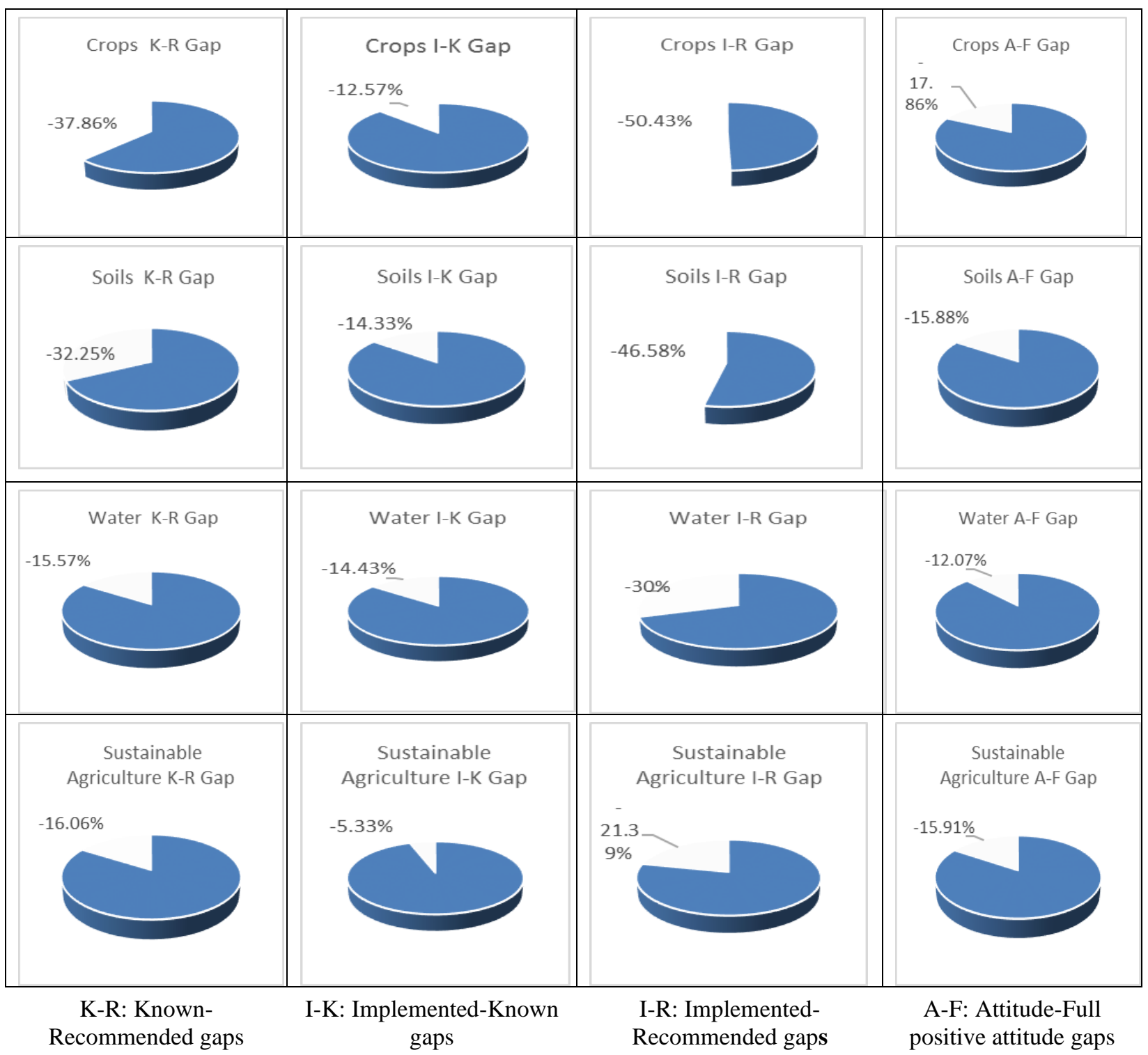

Figure 2. Farmers' behavioral gaps concerning sustainable agriculture

Source: the study's finding 
Table 7. Chi-Square values of the studied variables with farmers' knowledge, attitudes and implementation of sustainable agriculture practices

\begin{tabular}{lccc}
\hline Independent Variables & Knowledge & Attitudes & Implementation \\
\hline Age & $33.51^{* * *}$ & 5.23 & $20.01^{*}$ \\
Education & 11.77 & 7.85 & 8.28 \\
Family size & 5.29 & 0.288 & 3.52 \\
Occupation & 2.92 & 0.517 & 1.52 \\
Farm size & 8.29 & $10.96^{*}$ & $26.25^{* *}$ \\
Farming experience & 1.51 & 0.60 & $9.37^{*}$ \\
Availability of agricultural drainage & $9.45^{* *}$ & 0.629 & $7.37^{*}$ \\
Source of irrigation water & 5.49 & 3.21 & 6.08 \\
Type of irrigation system & 2.29 & 1.26 & 3.96 \\
Adequacy of irrigation water in the winter season & 1.02 & 0.902 & 1.45 \\
Adequacy of irrigation water in the summer season & $10.31^{*}$ & 1.99 & 5.59 \\
Farm animal holdings & 0.899 & 0.451 & 2.19 \\
Agricultural machinery holdings & 3.844 & 0.093 & 0.083 \\
Sufficient of the income & 7.27 & 1.851 & 3.180 \\
Attitudes towards environment & $9.97^{*}$ & $10.34^{* *}$ & $9.39^{*}$ \\
\hline
\end{tabular}

Source: The study's findings.

$* \mathrm{P} \leq 0.05 \quad * * \mathrm{P} \leq 0.01$

Factors related to farmers' behaviors on the sustainable agriculture practices

In order to determine factors related to farmers' behaviors towards sustainable agriculture, Chi-square was used to test the relationships between the farmers' knowledge, attitudes and implementation of overall sustainable agriculture practices (the total of plant, soils, and water practices) and the studies 15 socioeconomic variables. Results in table 7 show that four, two and five variables have significant relationships with farmers' knowledge, attitudes towards and implementation of sustainable agriculture practices, respectively. Finding revealed also that all statistical hypotheses could be rejected except the hypotheses no. 1, 7, 11, 15, 20, 30, $31,35,36,37$, and 45 .

This implies that farmers' "age" related to their knowledge and implementation of sustainable agriculture practices, their "farm size" related to their attitudes towards and implementation of sustainable agriculture practices, this result is consistent with what is known in the literature, that the size of the farm is one of the most important determinants of the use of sustainable practices such as modern irrigation systems and agricultural mechanization.

Findings also show that variable of "farming experience" related to their implementation of sustainable agriculture practices, "Availability of agricultural drainage" related to knowledge and implementation of sustainable agriculture practices, Availability of agricultural drainage facilitates the task of implementing sustainable agricultural practices, especially those related to irrigation water management in addition to improving agricultural soil properties

The variable of "Adequacy of irrigation water in the summer season" related to knowledge on sustainable agriculture practices, this my due to the smaller quantities of water discharged from the well than those discharged in winter, therefore, the adequacy of irrigation water in the summer season is one of the most important indicators of good management or sustainable management of irrigation water.

Finally, the variable of "Attitudes towards environment" related to their knowledge, attitudes and implementation of sustainable agriculture practices, this could be attributed to the fact that environmental sustainability cannot be separated from agricultural sustainability, as sustainable management of agricultural resources is an integral part of sustainable environmental practices.

\section{CONCLUSION AND RECOMMENDATIONS}

Based on the results obtained from the current research, it could be concluded that the respondents have different behavioral gaps with regard to all subscales of sustainable agriculture. The existence of knowledge gaps among farmers requires recommending the necessity of spend more efforts on awareness-raising to raise farmers' knowledge on sustainable agriculture practices.

Moreover, the study also concluded that there are application gaps between what farmers are implementing and what they already know, which 
requires more effort in urging farmers to implement sustainable agricultural practices that they already know. In addition to the need for more effort to urge farmers to be aware of and adopt sustainable farming practices.

The results of the current study can also be guided in drawing intervention plans and building extension programs for sustainable agriculture in the study area. Finally, the research recommends conducting more similar studies to identify the behavioral gaps for all agricultural activities, so that its results beside the results of the current research would serve as a cornerstone in building demand-based agricultural extension programs.

\section{REFERENCES}

Abdel-Salam, M.F.S. 2011. Measuring agricultural sustainability and perception of farmers and extension personnel of its technologies in Assiut governorate. PhD thesis, Faculty of Agriculture, Assiut University.

Abubakar, M.S. and M.L. Attanda. 2013. The Concept Sustainable Agriculture: Challenges and Prospects. 5th International Conference on Mechatronics (ICOM'13). IOP Conf. Series: Materials Sci. and Engineering 53. doi:10.1088/1757-899X/53/1/012001.

Alexander, P.A. and T.L. Jetton. 2000. Learning from text: A multidimensional and developmental perspective. In M.L. Kamil, P.B. Mosenthal, P.D. Pearson and R. Barr (Eds.), Handbook of reading research: Vol. III (pp. 285-310). Mahwah, NJ: Lawrence Erlbaum Associates.

Alexander, P.A., T.L. Jetton and J.M. Kulikowich. 1995. Interrelationship of knowledge, interest, and recall: Assessing a model of domain learning. J. of Educational Psychology. 87: 559-575.

Alonge, A.J. and R.R. Martin. 1995. Assessment of the Adoption of Sustainable Agriculture Practices: Implications for Agricultural Education. J. of Agricultural Education. 36(3): 34-42.

Alonge, A.J. and R. Martin. 1995. Assessment of the Adoption of Sustainable Agriculture Practices: Implications for Agricultural Education. J. Agric. Educ.3:34-42

Amani, O., P. Unai and N.P. Russell. 2007. Biodiversity Conservation and Productivity in Intensive Agricultural Systems. J. Agric. Econ. 58:308-329.

Chikwendu, D. O. and J.O. Arokoyo. 1997. Women and sustainable agricultural development in Nigeria. J. of Sustainable Agriculture. 11(1):53-69.

Crews, T., C. Mohler and A. Power. 1991. Energetics and Ecosystem Integrity: The Defining Principles of Sustainable Agriculture. American J. Alternative Agriculture. 6(3): 146-149.

Crosson, P.R. 1992. 'Sustainable agriculture. Quarterly Newsletter', Resources Future. 106: 14-17.

Curry, N., J. Ingram, J. Kirwan and D. Maye. 2012. Knowledge networks for sustainable agriculture in
England. Outlook on Agriculture. 41(4): 243-248 doi: 10.5367/oa.2012.0106

Diab, A. M. and H. M. Tohamy. 2016. Determinants of sustainable agriculture in new lands, Farafra, New valley governorate, Egypt. Egyptian j. desert research (EJDR). 66(2): 423-438.

Diab, H. M. and A. M. Diab. 2016. Toward building a scale for practices of sustainable agriculture in the Egyptian deserts. Egyptian J. Desert Research. 65(2): 373-388.

Eckert, E. and A. Bell. 2005. Invisible Force: Farmers' Mental Models and How They Influence Learning and Actions. J. Ext. 43(3). Available online: http://www.joe.org/joe/2005june/a2.php

FAO. 2014. Sustainability assessment of food and agriculture systems (SAFA). Food and Agriculture Organization of the United Nations, Rome.

Flora, C. B. 1992. Building Sustainable Agriculture: A New Application of Farming Systems Research and Extension. J. of Sustainable Agriculture. 2: 37-50.

Gebska, M., A. Grontkowska, W. Swiderek and B. Golebiewska. 2020. Farmer Awareness and Implementation of Sustainable Agriculture Practices in Different Types of Farms in Poland. Sustainability. 12(8022) doi:10.3390/su12198022.

Herberich, D.H., J.A. List. 2012. Digging into background risk: Experiments with farmers and students. Am. J. Agric. Econ. 94: 457-463.

Holdershaw, J. and $\mathrm{Ph}$. Gendall. 2008. Understanding and predicting human behavior. ANZCA08: Power and Place. Wellington, July 2008. Refereed Proceedings: http://anzca08.massey.ac.nz

Kambewa, E. V. 2007. Contracting for Sustainability: An Analysis of the Lake Victoria-EU. Nile Perch Chain: Wageningen Pers

Karami, E. 1995. Agricultural Extension: The question of sustainable development in Iran. J. of Sustainable Agriculture. 5(1/2):61-72.

Kielbasa B., I.O. Drangert, B. Ulen and K. Tonderski. 2016. Drivers and constraints for Polish farmer's implementation of measures to remediate nutrient leaching to waters. International Scientific J. Mechanization in Agriculture and Conserving of the Resources. Scientific Technical Union of Mechanical Engineering - Bulgarian Associate of Mechanization in Agriculture. 62(4): 22-26.

Kielbasa, B., S. Pietrzak, B. Ulen, J. Drangert and K. Tonderski. 2018. Sustainable agriculture: The study on farmers' perception and practices regarding nutrient management and limiting losses. J. Water Land Dev. 36:67-75. DOI: 10.2478/jwld-2018-0007.

Kraus, S. J. 1995. Attitudes and the prediction of behavior: A meta-analysis of the empirical literature. Personality and Social Psychology Bulletin. 21(1): 58-75.

Le Gal, P.Y., P. Dugue, G. Faure and S. Novak. 2011. How does research address the design of innovative agricultural production systems at the farm level? A review. Agric. Syst. 104, 714-728. 
Nastis, S.A., K. Mattas and G. Baourakis. 2019. Understanding Farmers' Behavior towards Sustainable Practices and Their Perceptions of Risk. Sustainability. 11(1303) doi:10.3390/su11051303.

Pretty, J., C. Toulmin, S. Williams. 2011 Sustainable intensification in African agriculture. International $\mathrm{J}$. of Agricultural Sustainability. 9(1): 5-24.

Schrader, P.G. and K.A. Lawless. 2004. The Knowledge, Attitudes \& Behaviors Approach: How to Evaluate
Performance and Learning in Complex Environments. Performance Improvement. 43(9): 8-15.

Sumane, S., I. Kunda, K. Knickel, A. Strauss, T. Tisenkopfs, I. Rios, M. Rivera, T. Chebach and A. Ashkenazy. 2018. Local and farmers' knowledge matters! How integrating informal and formal knowledge enhances sustainable and resilient agriculture. J. Rural. Stud. 59:232-241.

Weil, R.R. 1990. Defining and Using the Concept of Sustainable Agriculture. J. Agronomy Education. 19(2): 126-130.

\title{
الملخص العربي
}

\section{الفجوات السلوكية للمزارعين فيما يتعلق بالزراعة المستدامة في واحة الخارجة، محافظة الوادي الجديد،}

\author{
مصر \\ محمد ممدوح يعقوب، أحمد محمد دياب
}

الفجوة التطبيقية الفعلية نحو ؟.0\% هذا يعني أن المزارعين لا ينفذون حوالي ب.0\% من الممارسات التي يعرفونها، كما وصلت الفجوة بين مستوى التطبيق وجملة الممارسات

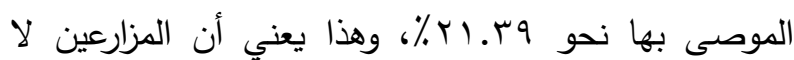
يطبقون نحو خُمس ممارسات الزراعة المستدامة الموصى بها. أما فجوة الإتجاهات فقد وصلت إلى 0.9 ٪ وهذا يعني أن المزارعين بحاجة إلى تحسين 11\% من إتجاهاتهم للوصول إلى الإتجاه الإيجابي الكامل نحو ممارسات الزراعة

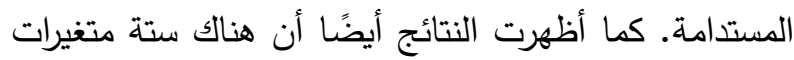
لها علاقة إقترانية بسلوك المزارعين المتعلق بممارسات الزراعة المستدامة، وهذه المتغيرات هي العمر، وحجم الحيازة المزرعية، وعدد سنوات الخبرة بالزراعة، ومدى توافر الصرف الزراعي، ومدى كفاية مياه الري في فصل الصيف، والإتجاهات نحو حماية البيئة. وبناءً على النتائج المتحصل عليها تم صياغة بعض الإستتتاجات والتوصيات.

الكلمات الدالة: معارف الزراع، الإتجاهات، التطبيق،

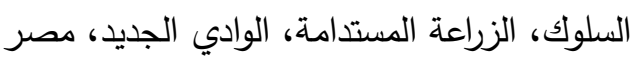

تتمثل أهداف هذا البحث في () تقدير سلوك المزارعين (المعارف والإتجاهات والممارسات) فيما يتعلق بالزراعة المستدامة (إدارة المحاصيل والأراضي والمياه) في واحة الخارجة، r) استكثاف الفجوات السلوكية للمزارعين فيما يتعلق بممارسات الزراعة المستدامة، ب) تحديد العوامل المرتبطة بسلوك المزارعين (المعارف مالإتجاهات والممارسات) المتعلق بالزراعة المستدامة في واحة الخارجة. ولتحقيق أهداف البحث تم اختيار قرية المنيرة بثكل عشوائي لتكون مكان إجراء البحث. وقد تم جمع البيانات من عينة

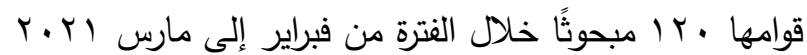
من خلال الإستبيان بعد إختباره بالمقابلة الشخصية. وإعتمادًا

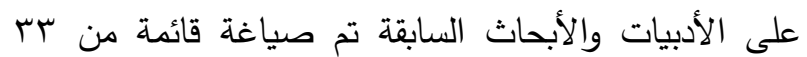

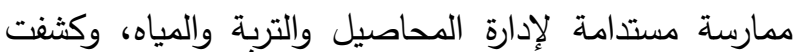

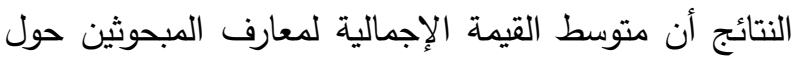

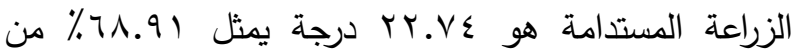
إجمالي درجة المعرفة، وبلغت الإتجاهات نحو .ـ^٪ من الدرجة الإجمالية، أما فيما يخص الممارسات فقد بلغ المتوسط نحو س.00\% من جملة الممارسات محل الدراسة. وفيما يتعلق بالفجوات السلوكية، كثفت النتائج أن الفجوة

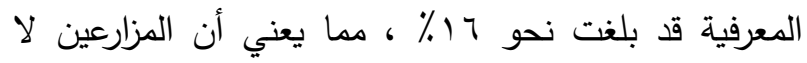
يعرفون نحو 1 \% من المعارف الموصى بها، وقد بلغت 